\title{
HUBUNGAN ANTARA KEMAMPUAN ANALISIS DAN KEMAMPUAN MATEMATIK DENGAN HASIL BELAJAR KIMIA SISWA (POKOK BAHASAN LARUTAN PENYANGGA KELAS XI SEMESTER GENAP SMA NEGERI 2 WONOGIRI TAHUN AJARAN 2017/2018)
}

\author{
Angger Pambayun Dimas Satrio Wibowo, Sri Mulyani ${ }^{\star}$, dan Ashadi \\ Program Studi Pendidikan Kimia, FKIP,Universitas Sebelas Maret, Surakarta, Indonesia \\ *Keperluan korespondensi, telp: 081548603734, email: srimulyaniuns@staff.uns.ac.id
}

\begin{abstract}
ABSTRAK
Penelitian ini bertujuan untuk mengetahui: (1) hubungan antara kemampuan analisis siswa dengan hasil belajar kimia pada materi larutan penyangga; (2) hubungan antara kemampuan matematik siswa dengan hasil belajar kimia pada materi larutan penyangga; dan (3) hubungan antara kemampuan analisis dan kemampuan matematik dengan hasil belajar kimia pada materi larutan penyangga. Penelitian ini menggunakan metode analisis regresi sederhana dan korelasi dengan perhitungan berbantuan software IBM SPSS version 22. Subjek penelitian adalah siswa kelas XI MIPA 5 dan XI MIPA 7 SMA Negeri 2 Wonogiri tahun ajaran 2017/2018 yang diambil dengan teknik One-Stage Cluster Sampling. Hasil penelitian menunjukkan bahwa: (1) Terdapat hubungan positif yang signifikan antara kemampuan analisis dengan hasil belajar kognitif materi larutan penyangga tergolong sangat kuat dengan persamaan garis regresinya $Y=63,38+$ $0,11 X_{1}$. Hal ini berdasarkan dari nilai yang didapatkan $r_{\text {hitung }}=0,814>r_{\text {tabel }}=0,442$ dengan besar sumbangan $66,2 \%$; (2) Terdapat hubungan positif yang signifikan antara kemampuan matematik dengan hasil belajar kognitif materi larutan penyangga tergolong kuat dengan persamaan garis regresinya $Y=61,18+0,17 X_{2}$. Hal ini berdasarkan dari nilai yang didapatkan $\mathrm{r}_{\text {hitung }}=0,799>\mathrm{r}_{\text {tabel }}$ $=0,442$ dengan besar sumbangan $63,8 \%$; dan (3) Terdapat hubungan positif yang signifikan antara kemampuan analisis dan kemampuan matematik dengan hasil belajar kognitif materi larutan penyangga dengan persamaan garis regresinya $Y=26,51+0,56 X_{1}+0,18 X_{2}$. Hal ini berdasarkan dari harga yang didapatkan $F_{\text {hitung }}=29,546>F_{\text {tabel }}=3,32$. Besarnya sumbangan relatif kemampuan analisis terhadap hasil belajar kognitif materi larutan penyangga adalah $81,6 \%$ dan kemampuan matematik $18,4 \%$ dan berbanding lurus dengan sumbangan efektifnya yaitu kemampuan matematik $12,2 \%$ dan kemampuan analisis $54,1 \%$.
\end{abstract}

Kata Kunci: Analisis Regresi, Hasil Belajar, Kemampuan Analisis, Kemampuan Matematis, Korelasi.

\section{PENDAHULUAN}

Berdasarkan putusan Peraturan Menteri Pendidikan dan Kebudayaan Republik Indonesia Nomor 160 tahun 2014 tentang Pemberlakuan Kurikulum Tahun 2006 dan Kurikulum 2013 dalam pasal 2 ayat 1 disebutkan bahwa satuan pendidikan dasar dan satuan pendidikan menengah yang telah melakukan Kurikulum 2013 selama tiga semester tetap melaksanakan Kurikulum 2013. Berlakunya kurikulum ini diharapkan dapat memperbaiki proses belajar sehingga dapat meningkatkan prestasi belajar peserta didik. Dengan meningkatnya prestasi belajar peserta didik maka kualitas pendidikan akan semakin baik [1]. Dengan adanya keputusan tersebut kurikulum pendidikan yang saat ini sedang diterapkan oleh SMA N 2 Wonogiri adalah Kurikulum 2013. Titik tumpunya yaitu bertujuan mendorong peserta didik atau siswa, mampu lebih baik dalam melakukan observasi, bertanya, mengkomunikasi-kan, dan bernalar apa yang mereka peroleh atau mereka ketahui setelah menerima materi pembelajaran. 
Pada kurikulum 2013, kimia merupakan salah satu mata pelajaran yang diajarkan di SMA yang menggunakan pendekatan saintifik. Kimia juga merupakan mata pelajaran wajib untuk siswa SMA program IImu Pengetahuan Alam (IPA) [2]. Kimia yang hakekatnya pengetahuan diperoleh berdasarkan fakta, hasil analisis, dan produk hasil eksperimen oleh para ahli, khususnya pada tingkat Sekolah Menengah Atas (SMA) menekankan peserta didik dalam penguasaan konsep-konsep kimia, saling berkaitan antar materi pelajaran serta penerapan dalam kehidupan sehari-hari.

Kegiatan pendidikan terjadi dalam lingkungan rumah (keluarga), sekolah, maupun masyarakat. Pada proses belajar yang mana sasaran utamanya adalah individu sebagai subjek belajar, maka faktor dari dalam diri siswa merupakan salah satu faktor yang sangat penting dalam menentukan keberhasilan belajar yang telah dilaksanakan. Hasil belajar merupakan bagian akhir dari proses belajar dengan kata lain tujuan dari belajar adalah mendapat hasil yang baik. Banyak siswa yang mengalami masalah dalam belajar akibatnya hasil belajar yang dicapai rendah. Untuk mengatasi hal tersebut perlu ditelusuri faktor internal yang mempengaruhi hasil belajar diantaranya kemampuan analisis dan kemampuan matematik pada diri siswa.

Kemampuan analisis adalah kemampuan untuk merinci atau menguraikan suatu masalah (soal) menjadi bagian-bagian yang lebih kecil (komponen) serta mampu untuk memahami hubungan diantara bagian-bagian tersebut [3]. Semakin tinggi tingkat kemampuan analisis siswa diharapkan akan semakin dalam pemahaman terhadap konsep materinya, sehingga hasil belajarnya juga semakin tinggi.

Kemampuan matematik yaitu kemampuan untuk mengoperasikan hitungan yang berwujud angka, sifat angka, atau sistem angka [4]. Kemampuan matematik memberikan peran yang sangat penting bagi tercapainya hasil belajar khususnya pada pembelajaran sains. Prestasi siswa yang mempunyai kemampuan matematika tinggi lebih baik daripada prestasi siswa yang mempunyai kemampuan matematika rendah [5]. Materi pokok materi larutan penyangga di SMA banyak berisi konsepkonsep yang cukup sulit untuk di pahami siswa karena menyangkut reaksi-reaksi kimia dan operasi matematika seperti penjumlahan, bentuk akar, pembagian, perkalian, dan logaritma. Perlunya siswa dalam menganalisis jenis larutan dan bagaimana reaksi tersebut dapat terjadi dan bagaimana sifat larutan tersebut juga sangat penting dalam pencapaian hasil belajar. Hal ini didapatkan berdasarkan hasil wawancara dengan beberapa siswa dan guru kimia di SMA Negeri 2 Wonogiri. Ini menyebabkan pelajaran kimia dan terutama pada materi larutan penyangga kurang menarik bagi siswa. Berdasarkan daftar nilai mata pelajaran kimia pada materi sebelumnya juga dapat diketahui bahwa hasil belajar siswa untuk materi asam basa pada tahun ajaran 2017/2018 hanya pada angka rata-rata 57 dari 3 kelas dengan total siswa 98 siswa. Sehingga dengan didapatkannya nilai rata-rata tersebut dapat disimpulkan bahwa masih banyak siswa yang belum mencapai KKM.

Setelah mengkaji karakteristik materi, kemampuan kognitif, dan berbagai aspek kemampuan matematik serta kemampuan analisis yang dibutuhkan, maka maka akan dilakukan penelitian mengenai hubungan antara kemampuan analisis dan kemampuan matematik dengan hasil belajar kimia siswa pada pokok bahasan larutan penyangga kelas XI semester genap di SMA Negeri 2 Wonogiri tahun ajaran 2017/2018.

\section{METODE PENELITIAN}

Penelitian ini menggunakan metode analisis regresi sederhana dan korelasi dengan proses perhitungan berbantuan software IBM SPSS version 22. Untuk lebih jelasnya dapat dilihat pada paradigma penelitian seperti terlihat pada pada Gambar 1. 


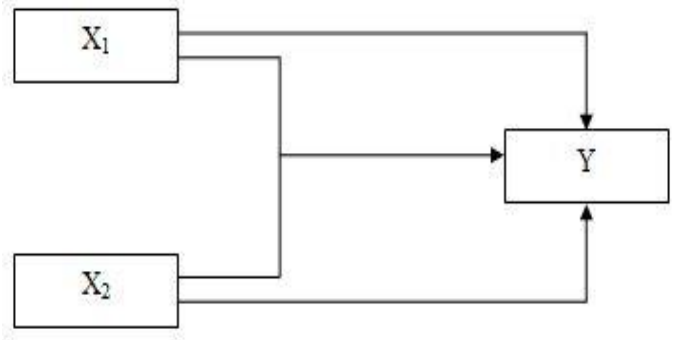

Gambar 1. Paradigma Penelitian

Keterangan:

$\mathrm{X}_{1}$ : Kemampuan analisis siswa

$\mathrm{X}_{2}$ : Kemampuan matematik siswa

$Y$ : Hasil belajar kimia kognitif

Penelitian ini dilakukan di SMA Negeri 2 Wonogiri. Populasi dalam penelitian ini adalah siswa kelas XI MIPA SMA Negeri 2 Wonogiri Tahun Ajaran 2017/2018. Pengambilan sampel dilakukan secara one-stage cluster sampling. Sampel yang terpilih adalah siswa kelas XI MIPA 5 sebagai kelas try-out dan XI MIPA 7 sebagai kelas penelitian.

Teknik pengumpulan data menggunakan: (1) dokumentasi nilai ulangan harian materi asam basa kelas XI MIPA SMA Negeri 2 Boyolali tahun ajaran 2017/2018; (2) instrumen tes untuk mengukur kemampuan Analisis; (3) instrumen tes untuk mengukur kemampuan Matematik; dan (4) instrumen tes untuk mengukur hasil belajar siswa materi larutan penyangga.

Teknik analisis data terdiri dari uji prasyarat analisis dan uji hipotesis. Uji prasyarat analisis meliputi uji normalitas, uji independensi, dan uji linearitas. Uji hipotesis menggunakan uji ANAVA. Analisis dilakukan dengan menggunakan bantuan software IBM SPSS version 22 dan perhitungan manual.

Instrumen yang digunakan dalam penelitian ini yaitu instrumen penilaian kognitif. Teknik analisis instrumen kognitif menggunakan uji validitas isi dengan formula Gregory. Dari hasil analisis diperoleh nilai CV tes kemampuan analisis dan tes kemampuan matematik sebesar 1,00 sedangkan tes kognitif materi larutan penyangga sebesar 0,956 . Kriteria yang digunakan adalah jika CV $\geq 0,700$ maka analisis dapat dilanjutkan, sehingga dari hasil yang diperoleh maka penelitian ini dapat dilanjutkan. Untuk uji reliabilitas menggunakan rumus KR-20 diperoleh nilai sebesar 0,805. Kriteria pengujian yang dipakai yaitu jika $r_{11} \geq 0,70$ maka tes hasil belajar yang sedang diuji dinyatakan telah memiliki reliabilitas yang tinggi (reliable), sehingga dari hasil yang diperoleh maka instrumen sudah teramsuk reliable. Selain itu, instrumen penilaian kognitif juga diuji tingkat kesukaran soal dan daya pembedanya menggunakan bantuan software ITEMAN. Setelah dilakukan analisis terhadap hasil uji coba instrumen penilaian kognitif diperoleh kesimpulan bahwa dari 23 soal yang diuji cobakan, 3 soal tergolong sukar, 15 soal tergolong sedang, dan 5 soal tergolong mudah. Dari 23 soal tersebut, juga diisimpulkan bahwa daya pembeda 4 soal tergolong baik, 16 soal tergolong cukup, dan 3 soal tergolong jelek.

\section{HASIL DAN PEMBAHASAN}

Data hasil penelitian yang diperoleh adalah data hasil belajar kognitif siswa, data kemampuan analisis siswa, dan data kemampuan matematik siswa. Data tersebut dirangkum dalam Tabel 1.

Tabel 1. Rangkuman Nilai Rata-Rata Data Penelitian

\begin{tabular}{lc}
\hline \multicolumn{1}{c}{ Jenis Penilaian } & $\begin{array}{c}\text { Nilai } \\
\text { Rata-Rata }\end{array}$ \\
\hline Hasil Belajar Kognitif & 72,07 \\
Kemampuan Analisis & 63,64 \\
Kemampuan Matematik & 55,60 \\
\hline
\end{tabular}

Tabel 1 tersebut merupakan hasil rangkuman yang berdasarkan pada distribusi frekuensi data yang didapatkan dalam penelitian. Hasil rangkuman data nilai-nilai tersebut digunakan untuk mengetahui adakah pengaruh variabelvariabel bebas dengan variabel terikatnya.

Pada penelitian ini dilakukan analisis terhadap hasil belajar yang didasarkan pada nilai ulangan harian asam basa untuk tahap awal penentuan uji normalitas sampel penelitian menggunakan metode Lilliefors. Data 
hasil uji normalitas tersebut dirangkum dalam Tabel 2.

Tabel 2. Rangkuman Hasil Uji Normalitas Sampel

\begin{tabular}{lc}
\hline \multicolumn{1}{c}{ Nilai UH Asam Basa } & Sig. \\
\hline Kelas XI MIPA 5 & 0,176 \\
Kelas XI MIPA 6 & 0,070 \\
Kelas XI MIPA 7 & 0,068 \\
\hline
\end{tabular}

Dari uji normalitas pada Tabel 2 diperoleh hasil bahwa kelas yang didapatkan berasal dari sampel yang berdistribusi normal dengan asumsi bahwa jika nilai Sig. > 0,05 maka sampel normal.

Sebelum dilakukan uji hipotesis, perlu dilakukan uji persyaratan analisis terhadap kelas penelitian yang diambil data nilainya meliputi uji normalitas, uji independensi, dan uji linearitas. Data hasil uji normalitasnya dirangkum dalam Tabel 3. Data hasil uji independensinya dirangkum dalam Tabel 4. Data hasil uji linearitas dan keberartian dirangkum dalam Tabel 5.

Tabel 3. Rangkuman Hasil Uji Normalitas Kelas XI MIPA 7

\begin{tabular}{lcc}
\hline \multicolumn{1}{c}{ Nilai Tes } & Sig. & Kesimpulan \\
\hline $\begin{array}{l}\text { Kemampuan } \\
\text { Analisis }\end{array}$ & 0,091 & Normal \\
$\begin{array}{l}\text { Kemampuan } \\
\text { Matematik }\end{array}$ & 0,079 & Normal \\
Hasil Belajar Kognitif & 0,051 & Normal \\
\hline
\end{tabular}

Hasil pengujian dari Tabel 3 diperoleh kesimpulan Sig. > 0,05 sehingga disimpulkan normal, artinya data diambil dari sampel yang berasal dari populasi berdistribusi normal. Dengan kata lain kelas penelitian yaitu kelas XI MIPA 7 SMA Negeri 2 Wonogiri tahun ajaran 2017/2018 tergolong normal. Dalam kelas tersebut siswa yang tidak pintar sekali dan pandai sekali jumlahnya hanya sedikit dan sebagian besar berada pada kategori sedang atau rata-rata. Hasil ini sesuai dengan hasil pengujian pada tahap pemilihan sampel sebelumnya yang mana juga menunjukkan hasil normal. Sehingga dapat disimpulkan kelas tersebut sesuai dengan salah satu persyaratan untuk diuji dengan teknik analisis regresi dan korelasi.

Tabel 4. Rangkuman Hasil Uji Independensi

\begin{tabular}{cccc}
\hline Hubungan & $r_{\text {hitung }}$ & $r_{\text {tabel }}$ & Keterangan \\
\hline $\mathrm{X}_{1}$ dan $\mathrm{X}_{2}$ & 0,145 & 0,344 & Independen \\
\hline
\end{tabular}

Dari Tabel 4 didapatkan kesimpulan bahwa hubungan antar $\mathrm{X}_{1}$ dan $\mathrm{X}_{2}$ bersifat independen. Dalam hal ini artinya antara $X_{1}$ dan $X_{2}$ tidak ada hubungan yang berarti atau tidak saling bergantung. Sehingga dapat ditarik kesimpulan bahwa $\mathrm{X}_{1}$ dan $\mathrm{X}_{2}$ dalam penelitian ini benar merupakan variabel yang memiliki pengaruh atau yang menjadi sebab terjadinya perubahan atau timbulnya variabel dependent.

Tabel 5. Rangkuman Hasil Uji Linearitas dan Keberartian

\begin{tabular}{ccccccc}
\hline Hubungan & $\mathrm{a}$ & $\mathrm{b}$ & $\mathrm{Uji}$ & $\mathrm{F}$ hitung & $\mathrm{F}$ tabel & Keterangan \\
\hline $\mathrm{X}_{1}$ dan $\mathrm{Y}$ & 63,38 & 0,11 & Linearitas & 1,26 & 2,42 & Linear \\
& & & Keberartian & 79,57 & 4,161 & Berarti \\
$\mathrm{X}_{2}$ dan $\mathrm{Y}$ & \multirow{2}{*}{61,18} & 0,17 & Linearitas & 0.94 & 2,58 & Linear \\
& & & Keberartian & 79,41 & 4,161 & Berarti \\
$\mathrm{X}_{1}, \mathrm{X}_{2}$ dan $\mathrm{Y}$ & \multirow{2}{*}{$26,51^{\text {bo }}$} & $0,56^{\mathrm{b} 1}$ & Linearitas & 1,05 & 2,34 & Linear \\
& & $0,18^{\mathrm{b} 2}$ & Keberartian & 29,546 & 3,32 & Berarti \\
\hline
\end{tabular}

Berdasarkan Tabel 5 didapatkan hasil bahwa model regresi antara $X_{1}$ dengan $\mathrm{Y}, \mathrm{X}_{2}$ dengan $\mathrm{Y}$, serta $\mathrm{X}_{1}$ dan $\mathrm{X}_{2}$ dengan $Y$ adalah linear dan signifikan atau berarti. Diperoleh juga persamaan regresi sebagai berikut: $Y=a+b X i$ [7] untuk masing-masing hubungan yang ada. Nilai a pada persamaan yang diperoleh merupakan nilai $Y$ yang dipotong oleh kurva linear pada sumbu vertikal $Y$ dengan kata lain, a adalah nilai $Y$ jika $X_{i}=0$. Nilai $b$ adalah kemiringan (slope) kurva linear yang menunjukkan 
besarnya perubahan nilai $Y$ sebagai akibat dari perubahan setiap unit nilai $X_{i}$.

Dengan hasil diatas telah menunjukkan bahwa uji persyaratan analisis telah terpenuhi, yaitu data normal, independen dan linear atau berarti, sehingga penelitian ini dapat dilanjutkan untuk melakukan tahap selanjutnya yakni tahap pengujian hipotesis.

Pengujian hipotesis I dan II menggunakan analisis korelasi product moment dan untuk pengujian hipotesis III menggunakan analisis dua prediktor pada uji linearitas. Hasil pengujian hipotesis tersebut secara berturut-turut dirangkum pada Tabel 6 dan 7 .

Tabel 6. Rangkuman Hasil Uji Hipotesis I dan II

\begin{tabular}{ccccc}
\hline Hipotesis & $r_{x y}$ & $r_{\text {tabel }}$ & Hubungan & Uji Keberartian \\
\hline I & 0,814 & 0,442 & Ada & Signifikan \\
II & 0,799 & 0,442 & Ada & Signifikan \\
\hline
\end{tabular}

Tabel 7. Rangkuman Hasil Uji Hipotesis III

\begin{tabular}{ccccc}
\hline Hipotesis & $\mathrm{R}$ & $\mathrm{F}_{\text {hitung }}$ & $\mathrm{F}_{\text {tabel }}$ & Uji Keberartian \\
\hline III & 0,663 & 29,546 & 3,32 & Signifikan \\
\hline
\end{tabular}

Penelitian korelasional memiliki tujuan untuk menentukan ada apa tidaknya hubungan antara dua variabel atau lebih, kearah manakah hubungan tersebut positif atau negatif, dan seberapa jauh hubungan yang ada antara dua variabel atau lebih yang dapat diukur. Penelitian korelasi mempelajari kontribusi yang terdapat pada variabel penyebab $(X)$ atau variabel bebas dan variabel akibat $(\mathrm{Y})$ atau variabel terikat. Sehingga pada penelitian ini dilibatkan kemampuan analisis $\left(X_{1}\right)$ dan kemampuan matematik $\left(X_{2}\right)$ sebagai variabel bebas dan hasil belajar kimia materi larutan penyangga (Y) sebagai variabel terikatnya.

Hasil analisis korelasi product moment akan memperoleh hasil koefisien korelasi sebesar ( $r$ ) yang selanjutnya untuk mengetahui kuatlemahnya hubungan (korelasi) akan dikonsultasikan pada kategori berikut:

$0-0,199$ : Sangat lemah

$0,20-0,399$ : Lemah

$0,40-0,599$ : Sedang

$0,60-0,799$ : Kuat

$0,80-1,0 \quad$ : Sangat kuat [6].

Pada hipotesis pertama, hasil pengujian analisis korelasi product moment untuk mengetahui ada tidaknya hubungan antara variabel bebas dan variabel terikat didapatkan nilai $r_{\text {hitung }}$ $(0,814)>r_{\text {tabel }}(0,442)$, hal ini berarti $\mathrm{H}_{0}$ ditolak dan $\mathrm{H}_{1}$ diterima. Dapat disimpulkan bahwa ada hubungan yang sangat kuat antara kemampuan analisis dengan hasil belajar siswa pada materi pokok larutan penyangga (Tabel 6).

Pada hipotesis kedua, hasil pengujian analisis korelasi product moment untuk mengetahui ada tidaknya hubungan antara variabel bebas dan variabel terikat didapatkan nilai $r_{\text {hitung }}$ $(0,799)>r_{\text {tabel }}(0,442)$, hal ini berarti $\mathrm{H}_{0}$ ditolak dan $\mathrm{H}_{1}$ diterima. Dapat disimpulkan bahwa ada hubungan yang kuat antara kemampuan analisis dengan hasil belajar siswa pada materi pokok larutan penyangga (Tabel 6).

Pada hipotesis ketiga, hasil uji analisis dua prediktor untuk mengetahui ada tidaknya hubungan antara variabelvariabel bebas dan variabel terikat menunjukkan nilai $F_{\text {hitung }}(29,546)>F_{\text {tabel }}$ $(3,32)$, hal ini berarti $\mathrm{H}_{0}$ ditolak dan $\mathrm{H}_{1}$ diterima. Dapat disimpulkan bahwa ada hubungan yang signifikan antara kemampuan analisis dan kemampuan matematik dengan hasil belajar kognitif materi larutan penyangga (Tabel 7).

Besarnya sumbangan relatif dan sumbangan efektif yang diberikan masing-masing variabel bebas diperoleh dari harga $\mathrm{JK}_{\text {regresi yang telah }}$ diketahui. Sehingga dari hasil analisis kontribusi dapat dirangkum seperti terlihat pada Tabel 8 dan 9. 
Tabel 8. Rangkuman Hasil Sumbangan Satu Variabel Bebas Terhadap Variabel Terikat

\begin{tabular}{ccc}
\hline Variabel & $\begin{array}{c}\text { Kemampuan } \\
\text { Analisis }\end{array}$ & $\begin{array}{c}\text { Kemampuan } \\
\text { Matematik }\end{array}$ \\
\hline Sumbangan & $66,2 \%$ & $63,8 \%$ \\
\hline
\end{tabular}

Dari Tabel 8 diketahui adanya sumbangan dari masing-masing variabel bebas terhadap variabel terikat. Untuk model regresi dengan satu variabel bebas terhadap $Y$ didapatkan hasil secara parsial bahwa $X_{1}>X_{2}$ sehingga disimpulkan kemampuan analisis memberi sumbangan atau peranan lebih besar terhadap hasil belajar kognitif materi larutan penyangga daripada kemampuan matematik secara masing-masing. Hal ini sesuai dengan soal materi yang di tes kan yaitu larutan penyangga dimana banyak soal yang memerlukan proses analisa terlebih dahulu yang benar diikuti dengan proses hitung yang benar juga dalam menyelesaikan soal.

Tabel 9. Rangkuman Hasil Sumbangan Dua Variabel Bebas Terhadap Variabel Terikat

\begin{tabular}{ccc}
\hline Variabel & $\begin{array}{c}\text { Kemampuan } \\
\text { Analisis }\end{array}$ & $\begin{array}{c}\text { Kemampuan } \\
\text { Matematik }\end{array}$ \\
\hline $\begin{array}{c}\text { Sumbangan } \\
\text { Relatif }\end{array}$ & $81,6 \%$ & $18,4 \%$ \\
$\begin{array}{c}\text { Sumbangan } \\
\text { Efektif }\end{array}$ & $54,1 \%$ & $12,2 \%$ \\
\hline
\end{tabular}

Untuk model regresi dengan dua variabel bebas terhadap $Y$ didapatkan hasil pada sumbangan relatif (SR) dan sumbangan efektif (SE) $X_{1}>X_{2}$. Hal ini menunjukkan dalam penjelasan hasil belajar larutan penyangga secara bersama-sama bahwa kemampuan analisis lebih dapat menjelaskannya daripada kemampuan matematik.

Kemampuan analisis adalah kemampuan untuk melakukan analisa, memproses, merangkum, dan menginterpretasikan data yang ada untuk menarik hasil kesimpulan dengan singkat namun penuh makna dalam mengetahui keadaan yang sebenarnya data tersebut. Dalam kemampuan analisis ini juga termasuk kemampuan menyelesaikan soal-soal yang tidak rutin, menemukan hubungan, membuktikan dan mengomentari bukti, dan merumuskan serta menunjukkan benarnya suatu generalisasi, tetapi baru dalam tahap analisis belum dapat menyusun. Kemampuan analisis penting dimiliki siswa karena siswa akan mampu mendudukan situasi, masalah, subjek, atau keputusan pada pemeriksaan yang mendalam. Siswa yang memiliki kemampuan analisis dapat menguji pernyataan berdasarkan standar objektif dan dapat menemukan akar permasalahan. Terkhusus dalam menghadapi persoalan materi larutan penyangga, kemampuan analisis dalam penelitian ini mampu menjelaskan setidaknya $54,1 \%$ secara efektif dari total $66,3 \%$ total pengaruhnya.

Kemampuan matematik adalah kemampuan menghubungkan antara bilangan dan prosedur operasional yang digunakan dalam penyelesaian masalah mengenai bilangan. Hasil akademik siswa tidak hanya ditentukan oleh kecerdasan intelektual, tetapi juga berhubungan dengan kemampuan matematik yang dimiliki. Adapun kemampuan matematik dapat meningkat sejalan dengan sering tidaknya siswa menghadapi masalah matematika. Kemampuan matematik siswa merupakan salah satu faktor lain yang seharusnya turut mendapat perhatian. Terkhusus dalam menghadapi persoalan materi larutan penyangga, kemampuan matematik dalam penelitian ini mampu menjelaskan setidaknya $12,2 \%$ secara efektif dari total $66,3 \%$ total pengaruhnya. Oleh karena itu, kemampuan matematik tidak boleh diabaikan dan wajib untuk terus diasah.

\section{KESIMPULAN}

Berdasarkan hasil penelitian yang telah dilakukan dapat disimpulkan bahwa:

1. Terdapat hubungan positif yang signifikan antara kemampuan analisis dengan hasil belajar kognitif materi larutan penyangga tergolong sangat kuat dengan persamaan garis regresinya $Y=63,38+0,11 X_{1}$. Hal ini 
ditunjukkan dengan didapatkannya nilai dari $r_{\text {hitung }}=0,814>r_{\text {tabel }}=0,442$. Besarnya sumbangan kemampuan analisis terhadap hasil belajar kognitif materi larutan penyangga adalah $66,2 \%$.

2. Terdapat hubungan positif yang signifikan antara kemampuan matematik dengan hasil belajar kognitif materi larutan penyangga tergolong kuat dengan persamaan garis regresinya $Y=61,18+0,17 X_{2}$. $\mathrm{Hal}$ ini ditunjukkan dengan didapatkannya nilai dari $r_{\text {hitung }}=0,799$ $>r_{\text {tabel }}=0,442$. Besarnya sumbangan kemampuan matematik terhadap hasil belajar kognitif materi larutan penyangga adalah $63,8 \%$.

3. Terdapat hubungan positif yang signifikan antara kemampuan analisis dan kemampuan matematik dengan hasil belajar kognitif materi larutan penyangga dengan persamaan garis regresinya $\mathrm{Y}=$ $26,51+0,56 X_{1}+0,18 X_{2}$. Hal ini ditunjukkan dengan didapatkannya dari harga $F_{\text {hitung }}=29,546>F_{\text {tabel }}=$ 3,32 . Besarnya sumbangan relatif kemampuan analisis terhadap hasil belajar kognitif materi larutan penyangga adalah $81,6 \%$ dan kemampuan matematik $18,4 \%$ dan berbanding lurus dengan sumbangan efektifnya yaitu kemampuan matematik $12,2 \%$ dan kemampuan analisis $54,1 \%$.

\section{UCAPAN TERIMA KASIH}

Penelitian ini dapat selesai dengan baik karena bantuan dari berbagai pihak. Oleh karena itu penulis mengucapkan terima kasih kepada :

1. Ibu Diana Muslichatun, S.Pd., selaku guru pengampu mata pelajaran kimia di SMA Negeri 2 Wonogiri yang telah mengijinkan peneliti menggunakan kelasnya untuk penelitian.

2. Siswa-siswi kelas XI MIPA 5 dan XI MIPA 7 SMA Negeri 2 Wonogiri yang telah bersedia menjadi subjek penelitian ini.

\section{DAFTAR RUJUKAN}

[1] Peraturan Menteri Pendidikan dan Kebudayaan. (2014). Peraturan Menteri Pendidikan dan Kebudayaan Republik Indonesia Nomor 160 Tahun 2014 Tentang Pemberlakuan Kurikulum Tahun 2006 dan Kurikulum 2013. Menteri Pendidikan dan Kebudayaan Republik Indonesia

[2] Kristyasari, M.L., Masykuri, M., dan Hastuti, B. (2015). Jurnal Pendidikan Kimia. 4(3): 31-38.

[3] Suherman, E. dan Sukjaya, Y. (1990). Petunjuk Praktis Untuk Melaksanakan Evaluasi Pendidikan Matematika. Bandung: Wijayakusumah 157.

[4] Firmansyah, F., Ariani, S.R,. dan Martini, K.S. (2014). Jurnal Pendidikan Kimia. 3(3): 49-56.

[5] Murti, M.M., Redjeki, T., dan Utomo, S.B. (2014). Jurnal Pendidikan Kimia. 3(4): 75-82.

[6] Sugiyono. (2007). Statistik Untuk Penelitian. Bandung: Alfabeta, cv.

[7] Sudjana. (1996). Metode Statistika. Bandung: Tarsito. 